\title{
UPAYA PENINGKATAN PRESTASI BELAJAR IPS MELALUI COOPERATIVE LEARNING PADA SISWA KELAS VIII DI SMP NEGERI 3 GAMPING SLEMAN YOGYAKARTA
}

\author{
Nadziroh \\ Program Studi Pendidikan Guru Sekolah Dasar FKIP Universitas Sarjanawiyata Tamansiswa Yogyakarta \\ Jl. Batikan Tuntungan UH III/1043 Umbulharjo Yogyakarta 55167 \\ Email: nadnadz88@yahoo.com
}

\begin{abstract}
This study is intended to increase the student's achievement and process to excute the social studies learning with Cooperative Learning approach. This study is a Classroom Action Research (CAR) implemented to $8^{\text {th }}$ grade students in SMPN 3 Gamping Sleman as the object of study. This study contains three cycles, starts from planning, implementation, monitoring, reflecting and improving. The data were collected by using learning achievement test, observations, and interviews. The data from learning achievement tests were analyzed by using the descriptive quantitative technique. The data from observations and interviews were analyzed by using the descriptive qualitative technique on the basics of the results of the observation and reflection. Findings suggest that by the Cooperative Learning approach implementation, the social studies can get its best result. The student's score increases. It is proved by the average score in each examination. At the first cycle, the average score is 66.44 ; the second cycle is 67.41 ; and the third cycles is 77.67
\end{abstract}

Key words: Cooperative Learning

\section{PENDAHULUAN}

Salah satu permasalahan pendidikan yang dihadapi oleh bangsa Indonesia adalah rendahnya mutu pendidikan khususnya pendidikan dasar dan menengah. Berbagai usaha telah dilakukan untuk meningkatkan mutu pendidikan nasional, antara lain melalui berbagai pelatihan dan peningkatan mutu guru, penyempurnaan kurikulum, pengadaan buku dan alat pelajaran, perbaikan sarana dan prasarana pendidikan lainnya serta peningkatan mutu manajemen sekolah. Banyaknya permasalahan di atas membuat pendidikan pada era globalisasi sekarang ini banyak mendapat sorotan, perhatian dan kritikan tajam bukan saja dari orang tua siswa, tetapi juga dari pemerintah dan kalangan legislatif. Orang tua siswa banyak berharap bahwa putra-putrinya akan mendapatkan pendidikan yang layak dan bermutu, sehingga di kemudian hari akan menjadi manusia yang pandai, terampil dan berakhlak mulia. Harapan masyarakat tersebut merupakan beban berat yang diletakkan pada pundak guru, karena masyarakat beranggapan bahwa pendidikan adalah merupakan tanggung jawab guru sepenuhnya. Padahal seharusnya, merupakan tanggung jawab bersama antara orang tua, masyarakat, tenaga pendidikan dan pemerintah.

Menurut penelitian yang dilakukan oleh Syarifudin Nurdin (2002: 79) menemukan bahwa fenomena rendahnya mutu pembelajaran IImu Pengetahuan Sosial disebabkan oleh sikap spekulatif dan instuitif guru dalam memilih model atau pendekatan pembelajaran. Demikian pula yang terjadi di sekolah-sekolah pada umumnya guru dalam menggunakan model atau metode pembelajaran dan pendekatan yang sesuai dengan tujuan serta materi pembelajaran. Dari hasil penelitian tersebut, menunjukkan rendahnya kualitas pendidikan IImu Pengetahuan Sosial karena belum optimalnya kemampuan guru Ilmu Pengetahuan Sosial dalam menggunakan model pembelajaran serta menjadi tantangan bagi guru untuk meningkatkan kinerjanya, khususnya pembelajaran IImu Pengetahuan Sosial yang dapat mendorong minat belajar siswa pada pelajaran IImu Pengetahuan Sosial sehingga pada akhirnya dapat meningkatkan hasil belajar Ilmu Pengetahuan Sosial.

Dalam hubungan dengan peningkatan kualitas guru dan perbaikan sistem pengajaran, maka setiap guru diharapkan mampu menyajikan pembelajaran yang menarik di 
depan kelas. Menarik dalam pengertian mudah dipahami oleh peserta didik tidak membosankan dan dalam penerimaannya. Pada kenyataannya, guru Ilmu Pengetahuan Sosial lebih banyak menggunakan metode ceramah pada saat mengajar. Hal ini membuat kebanyakan siswa menjadi mengantuk, kurang bergairah dalam belajar, yang pada akhirnya akan menurunkan minat siswa terhadap pembelajaran IImu Pengetahuan Sosial.

Untuk dapat menyajikan pembelajaran IPS yang menarik juga diperlukan adanya alat peraga dan sarana yang dapat menunjang terciptanya iklim pembelajaran yang menyenangkan. Kurangnya sarana alat peraga IPS seperti gambar-gambar, VCD, peta konsep, chart, dan sebagainya membuat guru hanya mengandalkan buku paket sebagai satu-satunya sumber pembelajaran. Hal ini semakin membuat pembelajaran IPS menjadi semakin tidak menarik dan membosankan bagi siswa. Diperparah lagi dengan rendahnya minat baca siswa. Ini dapat dilihat dari rendahnya prosentase kunjungan siswa di perpustakaan untuk membaca maupun meminjam buku. Apabila guru hanya mengandalkan buku paket sebagai satu-satunya sumber maka bisa dipastikan tujuan dari pembelajaran IPS akan sulit tercapai.

Peningkatan kualitas pendidikan khususnya hasil belajar IPS dapat ditempuh dengan pembelajaran yang bervariasi dan banyak melibatkan aktivitas siswa, yaitu dengan merancang pembelajaran yang efektif, efisien dan punya daya tarik sehingga dapat mendorong meningkatnya prestasi pada pembelajaran IPS akan semakin besar.

Pemilihan berbagai variasi metode mengajar dan model pembelajaran yang sesuai dengan kebutuhan dan karakteristik siswa, meliputi intelektual ataupun bakat yang berbedabeda akan dapat membantu meningkatkan hasil belajar siswa yang optimal. Guru perlu memahami berbagai pendekatan ataupun model pembelajaran di kelas. Apabila seorang guru telah melaksanakan proses belajar mengajar dengan menggunakan pendekatan dan model pembelajaran yang tepat, maka hasil yang dicapai tentu dapat membanggakan dan dengan sendirinya kualitas pendidikan akan meningkat. Tidak sedikit guru dalam melaksanakan tugas sehari-hari tidak mau bersusah payah mencari model yang cocok tetapi justru tenggelam dalam rutinitas mengajar yang didasarkan atas pengalaman dan melaksanakan tanpa mengetahui betapa kompleks sebenarnya proses mengajar itu.

Setiap pendekatan ataupun model yang dipilih pastinya mengandung kelebihan dan kelemahan, karena pada hakikatnya tidak ada metode pembelajaran yang sempurna. Karena itu guru harus pandai-pandai berinofasi dalam menyikapi segala realitas yang dijumpai dalam pelaksanaan proses belajar mengajar, agar tercipta pembelajaran yang efektif. Efisien dan melibatkan banyak aktivitas siswa sehingga tercipta suasana pembelajaran yang menyenangkan, yang pada akhirnya akan dapat meningkatkan hasil belajar siswa khususnya pada mata pelajaran IPS. Salah satu model pembelajaran yang sangat berguna untuk membantu siswa menumbuhkan kemampuan siswa dalam bekerja sama, berfikir kritis dan kemampuan membantu teman adalah dengan menerapkan metode Cooperative Learning atau pembelajaran kooperatif (Ibrahim dkk, 2000). Beberapa ahli berpendapat bahwa Cooperative Learning unggul dalam membantu siswa memahami konsep-konsep yang sulit. Sejumlah penelitian menunjukkan bahwa dalam setting kelas kooperatif, siswa banyak belajar dari satu tema ke tema yang lain di antaranya sesama siswa dari pada belajar dari guru (Ibrahim dkk, 2000).

Cooperative Learning memiliki banyak model pembelajaran. Dalam penelitian ini dipilih pembelajaran kooperatif yang menggunakan model pembelajaran Jigsaw dan model TGT, karena model pembelajaran ini banyak melibatkan aktivitas siswa sehingga dapat meningkatkan respon siswa terhadap proses pembelajaran yang pada akhirnya akan meningkatkan hasil belajar siswa pada mata pelajaran IPS. Untuk itu, berdasarkan fenomena persoalan pembelajaran IPS dan dalam rangka mengoptimalkan prestasi akademik siswa maka perlu kiranya dilaksanakan penelitian yang bertujuan untuk meningkatkan efektivitas dan efisiensi proses pembelajaran pada mata pelajaran IPS.

Berdasarkan uraian di atas, maka peneliti tertarik untuk melakukan penelitian mengenai "Keefektivan metode Cooperative Learning model Jigsaw dan model TGT untuk meningkatkan prestasi belajar IPS di SMP Negeri 3 Gamping Sleman" 


\section{TINJAUAN PUSTAKA}

\section{A. Hasil Belajar}

Menurut Nana Sudjana (2002: 22) bahwa hasil belajar adalah kemampuankemampuan yang dimiliki siswa setelah menerima pengalaman belajarnya. Hal senada disampaikan oleh Dimyati \& Mujiono (2009: 3) bahwa hasil belajar merupakan hasil dari suatu interaksi tindak belajar dan tindak mengajar. Dari sisi guru, tindak mengajar diakhiri dengan proses evaluasi hasil belajar, dari segi siswa, hasil belajar merupakan realisasi atau pemekaran dari kecakapan-kecakapan potensial atau kapasitas yang dimiliki seseorang (Nana Syaodih, 2009:102).

\section{B. Klasifikasi hasil belajar}

Pengklasifikasian hasil belajar dalam sistem pendidikan nasional, rumusan tujuan pendidikan menggunakan klasifikasi hasil belajar dari Bloom (Suharsimi, 1994: 112), yang secara garis besar membaginya menjadi 3 ranah yang dikenal dengan istilah taksonomi Bloom yaitu: ranah kognitif, ranah afektif dan ranah psikomotorik. Ketiga ranah tersebut menjadi objek penilaian hasil belajar, di mana masing-masing ranah terdiri dari sejumlah aspek yang saling berkaitan dan alat penilaian untuk setiap ranah yang mempunyai karakteristik sendiri-sendiri sebab setiap ranah berbeda dalam cakupan dan hakikat yang terkandung di dalamnya.

\section{Cara mengukur hasil belajar}

Pengetahuan yang terdapat pada diri siswa merupakan suatu prestasi utama dan penting. Oleh karena itu, dalam merencanakan pembelajaran perlu dimasukkan cara mengukur hasil belajar. Agar guru mengetahui tingkat pengetahuan siswa, maka guru harus menguji hasil belajar siswa tersebut dengan menggunakan tes yaitu tes hasil belajar. Siswa dikatakan tuntas dalam belajarnya apabila nilai siswa telah mencapai taraf penguasaan minimal yang diterapkan bagi setiap unit bahan yang dipelajarinya. Di SMP Negeri 3 Gamping Sleman pada mata pelajaran IPS standar ketuntasan belajarnya yaitu 7 .

\section{Cooperative Learning (Pembelajaran Kooperatif)}

Cooperative Learning adalah suatu model pembelajaran di mana siswa belajar dalam kelompok kelompok kecil yang memiliki tingkat kemampuan yang berbeda. Dalam menyelesaikan tugas kelompok, setiap anggota saling bekerja sama dan membantu untuk memahami suatu bahan pembelajaran. Belajar belum selesai jika salah satu teman dalam kelompok belum menguasai bahan pembelajaran. Cooperative Learning atau pembelajaran gotong royong adalah sistem pengajaran yang memberi kesempatan kepada anak didik untuk bekerja sama dengan sesama siswa dalam tugas-tugas terstruktur (Anita Lie, 2008: 12).

Model Cooperative Learning dapat digunakan secara efektif pada setiap tingkatan kelas untuk mengajarkan berbagai materi mulai dari keterampilan dasar, matematika, IPS, masalah-masalah sosial, bidang teknik sampai pemecahan masalah. Pembelajaran kooperatif berbeda dengan metode diskusi yang biasanya dilaksanakan di kelas, karena Cooperative Learning menekankan sebagai pembelajaran dalam kelompok-kelompok kecil di mana peserta didik belajar dan bekerja untuk mencapai tujuan seoptimal mungkin.

Pengorganisasian pembelajaran dapat dicirikan oleh struktur tugas, tujuan dan penghargaan kooperatif. Siswa yang bekerja dalam situasi pembelajaran yang kooperatif, didorong untuk selalu bekerja sama pada suatu tugas bersama dan siswa akan mengkoordinasikan usulannya untuk dapat menyelesaikan tugas tersebut. Siswa akan berbagi penghargaan apabila siswa berhasil sebagai kelompok. Menurut Slavin (1990: 50):

All cooperative learning methods share the idea that student work together to learn and are responssible for their teammates learning as well as teir own. In addition to the idea of cooperative work, student team learning methods emphasize the use of team goals and team success, which can be achieved only if all members of the team learn the objectives being taught. That is student team learning the students tasks are not to do something as a team but to learn something as a team.

Bahwa semua metode pembelajaran kooperatif memberi ide bahwa siswa bekerja sama untuk belajar dan bertanggung jawab terhadap kelompok belajarnya sebaik mereka sendiri, di samping untuk menunjukkan adanya 
kerja sama. Metode kelompok belajar menekankan pada penggunaan pencapaian dan kesuksesan kelompok mempelajari objek menjadi suatu pengajaran. Itu artinya, dalam kelompok belajar, tugas siswa tidak untuk melakukan sesuatu hal sebagai kelompok tetapi untuk mempelajari sesuatu sebagai sebuah kelompok.

Selama ini di SMP Negeri 3 Gamping Sleman ditemukan beberapa permasalahan yaitu di antaranya nilai hasil belajar pada mata pelajaran IImu Pengetahuan Sosial masih rendah, guru belum banyak menggunakan metode pembelajaran IPS yang banyak melibatkan aktivitas siswa, pengelolaan kelas berfokus pada guru sebagai sumber belajar, proses belajar mengajar IPS yang cenderung membosankan atau monoton. Salah satu alternatif untuk mengatasi permasalahan tersebut adalah dengan menerapkan Cooperative Learning pada pembelajaran IPS yang banyak melibatkan siswa

\section{Unsur-unsur Model Cooperative Learning}

Roger dan David Johnson mengatakan bahwa tidak semua kerja kelompok bisa dianggap Cooperative Learning. Untuk mencapai hasil yang maksimal, lima unsur model pembelajaran gotong royong harus diterapkan.(Anita Lie, 2008:31)

Hal tersebut senada dengan apa yang disampaikan oleh Johnson yang dikutip oleh Anila Lie (2008: 31) bahwa pembelajaran kooperatif mempunyai ciri atau unsur-unsur pokok: (1) Positive interdependence (saling ketergantungan positif), (2) Face-to-face interaction (interaksi secara tatap muka), (3) Individual accountability (akuntabilitas individu), (4) Interpersonal and small group skill (kemampuan berhubungan dalam kelompok kecil), (5) Group processing (proses pembentukan kelompok).

\section{Macam-macam Model Cooperative Learning}

Ada empat macam pembelajaran kooperatif yang bisa digunakan oleh para guru (Moh. Nur, 2005: 5) yaitu sebagai berikut (a) Metode Student Team Achievement Division (STAD) dan Teams Games tournament (TGT), (b) metode Jigsaw, (c) metode Group Investigation (GI), (d) metode Struktural.

1) Metode Student Team Achievement Division (STAD) dan Teams Games tournament (TGT).
Metode Student Team Achievement Division (STAD) dikembangkan oleh Robert Slavin dkk dari Universitas John Hopkins. Metode ini dipandang yang paling sederhana dan paling langsung dari pendekatan Cooperative Learning. Dalam Student Team Achievement Division (STAD) siswa dikelompokkan menjadi beberapa kelompok dengan anggota 4 sampai 5 orang dan setiap kelompok harus heterogen. Tiap anggota tim menggunakan lembar kerja akademik dan kemudian saling membantu untuk menguasai bahan ajar melalui tanya jawab antar anggota tim. Secara individual maupun tim, tiap minggu atau tiap 2 minggu dilakukan evaluasi oleh guru untuk menguasai pengetahuan siswa terhadap bahan akademik yang telah dipelajari. Tiap siswa atau tiap tim diberi skor atas penguasaan terhadap bahan ajar dan kepada individu atau tim yang meraih prestasi tinggi diberi penghargaan.

2) Metode Jigsaw

Metode ini dikembangkan oleh Elliot Aronson dkk, dari Universitas Texas dan kemudian diadopsi oleh Slavin dan kawankawan. Dalam penerapan Jigsaw siswa dibagi berkelompok dengan anggota kelompok 5 atau 6 siswa heterogen. Materi pelajaran diberikan kepada siswa dalam bentuk teks dan para siswa bertanggung jawab untuk mempelajari suatu bagian dari bahan tersebut. Para anggota dari berbagai tim yang berbeda mempunyai tanggung jawab untuk mempelajari suatu bagian akademik yang sama dan selanjutnya berkumpul untuk saling membantu. Selanjutnya para siswa kembali ke kelompok semula untuk mengajar anggota lain mengenai materi yang telah dipelajari dalam kelompok tersebut. Setelah diadakan pertemuan dan diskusi siswa dievaluasi secara individu mengenai bahan yang telah dipelajari. Individu atau tim memperoleh skor tinggi diberi penghargaan oleh guru.

3) Metode Group Investigation (GI)

Metode Group Investigation (GI) sering dipandang sebagai metode yang paling kompleks dan sulit untuk dilaksanakan dalam pembelajaran kooperatif. Kelas dibagi dalam kelompok yang beranggotakan 5 sampai 6 siswa. Siswa disuruh memilih topik yang ingin dipelajari, mengikuti investigasi yang mendalam terhadap berbagai sub topik yang telah dipilih, kemudian menyajikan suatu laporan 
di depan kelas. Selanjutnya guru beserta siswa melaksanakan evaluasi mengenai kontribusi tiap kelompok terhadap pekerjaan kelas sebagai suatu keseluruhan.

4) Metode Struktural

Metode ini dikembangkan oleh Specer Kagan dkk. Meskipun banyak memiliki kesamaan dengan metode lainnya, metode struktural menekankan pada strukturstruktur khusus yang dirancang untuk mempengaruhi pola-pola interaksi siswa. Metode ini terdiri dari 2 macam model yaitu:

(1) Numered Head Together dan (2) ThinkPair-Share (TPS).

a) Numered Head Together

Metode yang dikembangkan oleh Specer Kagan ini melibatkan para siswa dalam mereviu bahan yang tercakup dalam suatu pelajaran dan mengecek atau memeriksa pemahaman siswa mengenai isi pelajaran tersebut.

b) Strategi Think-Pair-Share (TPS)

Think-Pair-Share (TPS) atau berpikir berpasangan berbagi jenis pembelajaran kooperatif yang dirancang untuk mempengaruhi pola interaksi siswa. Struktur yang dikembangkan ini dimaksudkan sebagi alternatif terhadap struktur kelas tradisional. Struktur ini menghendaki siswa bekerja sama saling membantu dalam kelompok kecil (2-6 anggota) dan lebih dicirikan oleh penghargaan kooperatirf dari pada penghargaan individual.

(1) Makna Strategi Think-Pair-Share (TPS)

Menurut Nurhadi dkk dalam modulnya, model Think-Pair-Share (TPS) pertama kali dikembangkan oleh Frank Lyman dan koleganya di Universitas Maryland pada tahun 1985. Frank Lyman menyatakan bahwa ThinkPair-Share (TPS) merupakan suatu cara yang efektif untuk mengganti suasana pola diskusi kelas. Think-Pair-Share (TPS) menurut Slavin (1990: 132) adalah:

This simple but very useful method was developed by Frank Lyman of University of Maryland. When the teacher present a lesson to the class, student sit in pairs within their teams. The teacher poses question it the class. Student are instructed to think of an answer on their own, then to pair with their partners it reach consensus on an answer finally, the teacher asks student to share their agreed upon answer with the rest of the class.

Think-Pair-Share (TPS) adalah sebuah metode yang sederhana tetapi sangat berguna ketika guru menerangkan pelajaran di depan kelas, siswa-siswa duduk berpasangan dalam kelompoknya. Guru memberikan pertanyaan keseluruhan kelas. Siswa diperintahkan untuk memikirkan jawaban masing-masing. Kemudian dengan masing-masing pasangannya, untuk mencari kesepakatan jawaban. Terakhir guru menyuruh siswa untuk berbagi jawaban dengan seluruh siswa.

\section{Langkah-langkah pada model pembelajaran Koperatif (Cooperative Learning)}

Langkah-langkah pembelajaran Koperatif (Cooperative Learning) adalah:

1) Memberikan gambaran umum dan menjelaskan kegiatan kelompok

2) Membagi siswa dalam kelompok-kelompok kecil

3) Membagi tugas masing-masing kelompok

4) Tiap-tiap kelompok mempresentasikan hasil kerja

5) Bantuan terhadap kelompok yang mengalami kesulitan

6) Guru dan siswa menyimpulkan hasil kerja kelompok

\section{E. Pembelajaran IPS di SMP}

Mata pelajaran IPS di SMP dalam kurikulum KBK disebut dengan istilah Pengetahuan Sosial. Mata pelajaran Pengetahuan Sosial ini pada jenjang SMP mengambil bahan ajar dari cabang-cabang ilmu sosial, khususnya sosiologi, geografi, ekonomi, sejarah dan kewarganegaraan. Dengan demikian mata pelajaran Pengetahuan Sosial di SMP merupakan perpaduan dari mata pelajaran dan materi sosiologi, ekonomi, sejarah dan kewarganegaraan. Pengertian IPS menurut Barth (1990: 360) yaitu: Social studies was assigned the mission of citizenship education. That mission included the study of personal social problems, man interdisciplinary integrated school curriculum that would emphasize the practice of decision making. IPS membawa misi pendidikan kewarganegaraan di mana di dalam misi tersebut dikandung pembelajaran tentang masalah-masalah individu atau sosial dalam interdisipliner kurikulum sekolah yang 
terintegrasi yang akan menekankan pada pengambilan keputusan yang praktis.

Menurut National Council for Social Studies (NCSS) Ilmu Pengetahuan Sosial didefinisikan sebagai berikut:

"Social studies is the integrated study of the social sciences and humanities to promote civic competence. Within the school program, social studies provides coordinate, systematic study drawing upon such disciplines as anthropology, archeology. Economics, geography, history, law, philosphy, political science, psychology, religion, and spciology, as well as appropiate content from the humanities, mathematics and natural sciences. The primary purpose of social studies is to help young people develop the ability to make informed and reasoned decisions for the public good as citizens of a culturally diverse, democratic society in an interdependent world."

IPS merupakan suatu bidang studi, yakni kombinasi atau hasil pemfusian atau perpaduan dari sejumlah mata pelajaran, seperti ilmu bumi, ekonomi, sejarah, anthropologi, dan sebagainya

\section{METODE PENELITIAN}

Jenis penelitian ini adalah penelitian tindakan kelas atau classroom action research. Pemilihan jenis penelitian ini didasarkan bahwa permasalahan yang terjadi di dalam kelas merupakan masalah yang memerlukan penanganan melalui proses pembelajaran.

Dalam penelitian tindakan kelas, partisipan merupakan salah satu yang mutlak harus ada, baik sebagai pelaksana tindakan ataupun sebagai observer. Penelitian tindakan kelas ini menggunakan sistem siklus dengan model spiral. Menurut Kemmis \& Taggart (1993: 32) karena dengan menggunakan model ini apabila dalam awal pelaksanaan tindakan ditemukan adanya kekurangan maka perbaikan masih dapat dilanjutkan pada siklus berikutnya sampai mencapai target yang diinginkan. Menurut Kemmis \& Taggart ada empat komponen penelitian dalam setiap siklus yaitu perencanaan, pelaksanaan tindakan, observasi dan refleksi.

\section{HASIL PENELITIAN}

Siklus I terdiri dari 4 (empat) pertemuan, dengan waktu masing-masing $2 \times 40$ menit, yaitu: tanggal 11, 14, 18 dan 21 Januari. Pada pertemuan terakhir, selama 40 menit dilakukan penilaian terhadap hasil belajar IPS.
Sesuai dengan kaidah pembelajaran dengan pendekatan Cooperative Learning model STAD, tahapan pelaksanaan tindakan diawali dengan presentasi kelas oleh guru, dilanjutkan dengan kerja tim. Di akhir siklus dilakukan kuis secara individual. Selain penghargaan individu, penghargaan juga dilakukan secara kelompok.

Pada pertemuan pertama selama 80 menit, proses pembelajaran masih lebih didominasi guru. Dari hasil pengamatan diperoleh: waktu yang digunakan aktivitas guru 45 menit $(61,11 \%)$ dan aktivitas siswa 25 menit (38,89\%). Dari 36 siswa yang hadir, jumlah siswa yang aktif memperhatikan adalah 29 orang $(85,29 \%)$, jumlah siswa yang aktif berpartisipasi adalah 3 siswa $(5,88 \%)$, dan jumlah siswa yang aktif bekerja sama adalah 23 siswa $(64,71 \%)$.

Dari pengamatan pertemuan kedua selama 80 menit, diperoleh: waktu yang digunakan untuk aktivitas guru adalah 35 menit dan waktu yang digunakan untuk aktivitas siswa juga 45 menit. Dari 36 siswa yang hadir, diperoleh jumlah siswa yang aktif memperhatikan adalah 26 siswa (74,29\%), jumlah siswa yang aktif berpartisipasi adalah 5 siswa $(14,29 \%)$, dan jumlah siswa yang aktif bekerja sama adalah 26 siswa $(71,43 \%)$.

Pada pertemuan ketiga selama 80 menit, proses pembelajaran sudah lebih didominasi siswa. Dari hasil pengamatan diperoleh waktu yang digunakan untuk aktivitas guru adalah 35 menit dan untuk aktivitas siswa juga 45 menit. Dari 36 siswa yang hadir, diperoleh banyak siswa yang aktif memperhatikan adalah 29 siswa (82,86\%), banyak siswa yang aktif berpartisipasi adalah 4 siswa(8,57\%), dan banyak siswa yang aktif bekerja sama adalah 25 siswa $(71,43 \%)$.

Pada pertemuan keempat selama 40 menit kemudian evaluasi 40 menit. Dari hasil pengamatan diperoleh waktu yang digunakan untuk pembelajaran adalah 40 menit, diperoleh: waktu untuk aktivitas guru adalah 10 menit dan untuk aktivitas siswa juga 30 menit. Dari 36 siswa yang hadir, diperoleh banyak siswa yang aktif memperhatikan adalah 30 siswa $(87,5 \%)$, banyak siswa yang aktif berpartisipasi adalah 3 siswa (6,25\%), dan banyak siswa yang aktif bekerja sama adalah 23 siswa $(71,88 \%)$.

Siklus II terdiri dari 4 (empat) pertemuan, dengan wktu masing-masing 2 x 40 menit, yaitu: tanggal 25 dan 28 Januari, 1 dan 4 februari. Pada pertemuan terakhir, selama 40 menit dilakukan penilaian terhadap hasil belajar IPS. 
Sesuai dengan kaidah pembelajaran dengan pendekatan Cooperative Learning model TPS, tahapan pelaksanaan tindakan diawali dengan presentasi kelas oleh guru, dilanjutkan dengan kerja tim. Di akhir siklus dilakukan kuis secara individual. Selain penghargaan individu, penghargaan juga dilakukan secara kelompok.

Pada pertemuan pertama siklus II selama 80 menit, proses pembelajaran dominasi guru sudah berkurang. Dari hasil pengamatan diperoleh: waktu yang digunakan aktivitas guru 25 menit $(27,78 \%)$ dan aktivitas siswa 55 menit $(72,22 \%)$. Dari 36 siswa yang hadir, jumlah siswa yang aktif memperhatikan adalah 29 orang (85,29\%), jumlah siswa yang aktif berpartisipasi adalah 3 siswa (5,88\%), dan jumlah siswa yang aktif bekerja sama adalah 23 siswa $(64,71 \%)$.

Dari pengamatan pertemuan kedua selama 80 menit, diperoleh: waktu yang digunakan untuk aktivitas guru adalah 20 menit dan waktu yang digunakan untuk aktivitas siswa juga 60 menit. Dari 36 siswa yang hadir, diperoleh jumlah siswa yang aktif memperhatikan adalah 30 siswa (74,29\%), jumlah siswa yang aktif berpartisipasi adalah 5 siswa $(14,29 \%)$, dan jumlah siswa yang aktif bekerja sama adalah 24 siswa $(71,43 \%)$.

Pada pertemuan ketiga selama 80 menit, proses pembelajaran sudah lebih didominasi siswa. Dari hasil pengamatan diperoleh waktu yang digunakan untuk aktivitas guru adalah 20 menit dan untuk aktivitas siswa juga 60 menit. Dari 36 siswa yang hadir, diperoleh jumlah siswa yang aktif memperhatikan adalah 29 siswa $(82,86 \%)$, banyak siswa yang aktif berpartisipasi adalah 4 siswa (8,57\%), dan jumlah siswa yang aktif bekerja sama adalah 25 siswa $(71,43 \%)$.

Pada pertemuan keempat selama 40 menit kemudian evaluasi 40 menit. Dari hasil pengamatan diperoleh waktu yang digunakan untuk pembelajaran adalah 40 menit, diperoleh: waktu untuk aktivitas guru adalah 10 menit dan untuk aktivitas siswa juga 30 menit. Dari 36 siswa yang hadir, diperoleh jumlah siswa yang aktif memperhatikan adalah 30 siswa $(87,5 \%)$, jumlah siswa yang aktif berpartisipasi adalah 3 siswa $(6,25 \%)$, dan jumlah siswa yang aktif bekerja sama adalah 23 siswa $(71,88 \%)$.

Siklus III terdiri dari 3 (tiga ) pertemuan, dengan waktu masing-masing 2 × 40 menit, yaitu: tanggal 8,11 , dan 15 Februari. Pada pertemuan terakhir, selama 40 menit dilakukan penilaian terhadap hasil belajaran IPS.
Sesuai dengan kaidah pembelajaran dengan pendekatan Cooperative Learning model Jigsaw, tahapan pelaksanaan tindakan diawali dengan presentasi kelas oleh guru, dilanjutkan dengan kerja tim. Di akhir siklus dilakukan kuis secara individual. Selain penghargaan individu, penghargaan juga dilakukan secara kelompok.

Pada pertemuan pertama siklus III selama 80 menit, proses pembelajaran dominasi guru sudah berkurang. Dari hasil pengamatan diperoleh: waktu yang digunakan aktivitas guru 20 menit $(27,78 \%)$ dan aktivitas siswa 60 menit $(72,22 \%)$. Dari 36 siswa yang hadir, jumlah siswa yang aktif memperhatikan adalah 30 orang $(85,29 \%)$, jumlah siswa yang aktif berpartisipasi adalah 3 siswa (5,88\%), dan jumlah siswa yang aktif bekerja sama adalah 22 siswa $(64,71 \%)$.

Dari pengamatan pertemuan kedua selama 80 menit, diperoleh: waktu yang digunakan untuk aktivitas guru adalah 20 menit dan waktu yang digunakan untuk aktivitas siswa juga 60 menit. Dari 36 siswa yang hadir, diperoleh banyak siswa yang aktif memperhatikan adalah 30 siswa (74,29\%), banyak siswa yang aktif berpartisipasi adalah 5 siswa $(14,29 \%)$, dan banyak siswa yang aktif bekerja sama adalah 24 siswa $(71,43 \%)$.

Pada pertemuan ketiga selama 80 menit, proses pembelajaran sudah lebih didominasi siswa. Dari hasil pengamatan diperoleh waktu yang digunakan untuk aktivitas guru adalah 20 menit dan untuk aktivitas siswa juga 60 menit. Dari 36 siswa yang hadir, diperoleh banyak siswa yang aktif memperhatikan adalah 29 siswa $(82,86 \%)$, banyak siswa yang aktif berpartisipasi adalah 4 siswa (8,57\%), dan banyak siswa yang aktif bekerja sama adalah 25 siswa $(71,43 \%)$.

Pada siklus I, proses pembelajaran dengan penerapan pendekatan Cooperative Learning model STAD masih belum sempurna. Waktu yang dibutuhkan untuk menyelesaikan 1 (satu) sub kompetensi lebih banyak dari waktu yang disediakan, yang biasanya menggunakan pendekatan yang konvensional. Pada siklus II dan siklus III, proses pembelajaran dengan penerapan pendekatan Cooperative Learning model TPS dan Jigsaw sudah menunjukkan sempurna. 


\section{PEMBAHASAN}

\section{Peningkatan keaktifan, perhatian, partisipasi dan kerjasama siswa.}

Keaktifan siswa yang ditandai dengan dominasi siswa dalam pembelajaran, perhatian siswa, partisipasi siswa, dan kerjasama siswa, belum dan selama dilakukan tindakan, dapat diamati dalam tabel berikut ini

Tabel 1. Keaktifan Siswa dan Guru

\begin{tabular}{llccc}
\hline No & URAIAN & \multicolumn{3}{c}{ PRESENTASE } \\
\cline { 3 - 5 } & & Siklus I & Siklus II & Siklus III \\
\hline 1 & Waktu guru aktif & 75 & 43,06 & 22,22 \\
2 & Waktu siswa aktif & 25 & 56,94 & 77,78 \\
3 & Perhatian & 45 & 82,48 & 94,29 \\
4 & Partisipasi & 10 & 8,75 & 25,71 \\
5 & Kerjasama & - & 69,89 & 97,14 \\
\hline
\end{tabular}

Berdasarkan tabel di atas, dapat dilihat bahwa waktu siswa aktif dalam pembelajaran dari waktu ke waktu mengalami peningkatan. Dominasi guru semakin berkurang sedangkan dominasi siswa semakin bertambah. Peningkatan perhatian dan kerjasama siswa cukup signifikan. Partisipasi siswa sudah mengalami kecenderungan meningkat, walaupun belum bisa maksimal.

Sampai akhir siklus III masih ada siswa yang melakukan gangguan belajar. Berdasarkan diskusi dengan guru IPS dan juga guru mata pelajaran lain, ternyata siswa yang melakukan gangguan belajar tersebut juga sering melakukan gangguan belajar pada mata pelajaran lain. Hal ini penulis sampaikan kepada guru BK untuk ditindaklanjuti.

\section{Peningkatan Hasil Belajar Siswa}

Peningkatan hasil belajar siswa dapat diketahui bahwa dari 36 siswa, terdapat 26 siswa yang mengalami kenaikan pada ketiga siklus, terdapat 9 siswa yang mengalami penurunan pada evaluasi akhir siklus I tetapi mengalami kenaikan pada siklus II dan III. Sedangkan 1 siswa mengalami kenaikan pada evaluasi akhir siklus I tetapi mengalani penurunan pada siklus II dan siklus III. Setelah diteliti, siswa tersebut juga merupakan siswa yang selalu melakukan gangguan belajar sampai akhir siklus III. Dengan demikian, secara umum hasil belajar siswa secara individu cenderung mengalami peningkatan.

\section{Dampak terhadap peningkatan kompetensi guru.}

Penerapan pendekatan Cooperative Learning menimbulkan dampak positif terhadap peningkatan kompetensi guru. Dari awal siklus I sampai siklus III, peningkatan kompetensi guru tersebut dapat dilihat pada tabel di bawah ini:

Tabel 2. Peningkatan Kompetensi Guru

\begin{tabular}{|c|c|c|}
\hline NO & SEBELUM & SESUDAH \\
\hline 1 & $\begin{array}{l}\text { Guru cenderung asyik dengan } \\
\text { dirinya sendiri }\end{array}$ & Guru lebih memperhatikan siswa \\
\hline 2 & Pertanyaan guru diajukan ke kelas & $\begin{array}{l}\text { Pertanyaan guru diajukan kepada siswa } \\
\text { secara individual }\end{array}$ \\
\hline 3 & $\begin{array}{l}\text { Soal latihan dikerjakan bersama- } \\
\text { sama }\end{array}$ & $\begin{array}{l}\text { Soal latihan dikerjakan secara individu } \\
\text { dengan tidak membawa buku }\end{array}$ \\
\hline 4 & $\begin{array}{l}\text { Guru belum terlalu peduli dengan } \\
\text { siswa yang memiliki kemapuan } \\
\text { kurang }\end{array}$ & $\begin{array}{l}\text { Guru lebih memperhatikan siswa yang } \\
\text { memiliki kemampuan kurang }\end{array}$ \\
\hline
\end{tabular}




\section{KESIMPULAN DAN SARAN}

\section{A. Kesimpulan}

Berdasarkan data yang diperoleh dan pembahasan hasil penelitian, ditemukan simpulan sebagai berikut:

Penerapan pendekatan Cooperative Learning pada pembelajaran IPS di kelas VIII E SMP negeri 3 Gamping Sleman dapat meningkatkan prestasi belajar siswa. Hal ini dapat dibuktikan dengan nilai rata-rata pada evaluasi tiap siklus I nilai rata-rata yaitu: 64,44 ; siklus II nilai rata-rata yaitu: 67,41 dan siklus III nilai rata-rata IPS adalah 77,67.

\section{B. Saran}

Berdasarkan pada simpulan dan implikasi penelitian yang telah dikemukakan, terdapat beberapa saran yaitu:

1. Saran Kepada Sekolah

Cooperative Learning model Jigsaw sebagai salah satu pendekatan pembelajaran yang telah terbukti mampu meningkatkan prestasi belajar IPS. Selain itu, perhatian dan kepedulian guru juga meningkat. Hal ini perlu menjadi perhatian sekolah agar mengadakan sosialisasi pendekatan Cooperative Learning dan memberikan kesempatan, fasilitas serta motivasi kepada para guru sehingga lebih memahami pendekatan Cooperative Learning .

Secara umum hendaknya dikembangkan budaya penelitian pada setiap guru untuk mampu melihat permasalahan dalam proses pembelajaran, mampu menganalisa dan mampu melakukan Penelitian Tindakan Kelas guna peningkatan efektifitas mata pelajaran yang diampu.

\section{Saran Kepada Guru}

Kepada para guru disarankan agar melaksanakan pembelajaran dengan pendekatan Cooperative Learning. Dengan pendekatan Cooperative Learning pencapaian hasil pembelajaran akademik meningkat. Pendekatan Cooperative Learning juga mampu meningkatkan rasa kebersamaan antar teman, tanggung jawab, kerja sama dan jiwa sosial siswa.

3. Saran Kepada peneliti Lain.

Melalui pendekatan Cooperative Learning ditemukan bahwa mampu meningkatkan perhatian, partisipasi, kerjasama, ketuntasan belajar dan keaktifan siswa serta perhatian dan kepedulian guru. Hal ini dapat digunakan sebagai informasi secara empirik yang dapat digunakan sebagai acuan bagi para peneliti lain. Disarankan kepada peneliti lain, agar lebih cermat dalam observasi awal sehingga mampu menemukan permasalahan yang tepat sehingga mampu melahirkan hipotesis tindakan yang tepat dan pada gilirannya mampu merumuskan solusi yang optimal.

\section{DAFTAR PUSTAKA}

Anita Lie. (2009). Cooperative learning (mempraktekkan cooperative learning di ruang-ruang kelas). Jakarta: PT Grassindo.

Barth. J. L. (1996). Method of instruction in social studies education. Lanham Maryland: University Press of Amerika.

Dimyati \& Mudjiono. (2009). Belajar dan pembelajaran. Jakarta: Rineka Cipta

Ellis, Arthur K. (1991). How to integrated the curricula. Iliois: Skylight Publishing Inc, Palatine.

Jarolimek, John. (1986). Social studies in elemtary education. New York: Mecmilan Publishing Company.

Kemmis, S, \& Taggart, R.Mc. (1988). The action research planner. Victoria: Deakin University.

Moh. Numan Sumantri. (2001). Menggagas pembaharuan pendidikan ips. Bandung: remaja Rosdakarya.

Moh. Nur. (2005). Pembelajaran kooperatif. Surabaya: Unesa

Moh. Uzer Usman. (2002). Menjadi guru profesional. Bandung: PT Remaja Rosadakarya.

N. Daldjoeni. (1981). Dasar-dasar ilmu pengetahuan sosial. Bandung: Alumni.

Nana Sudjana. (2002). Penilaian hasil belajar proses dalam mengajar. Bandung: Rosadakarya 
Nana Syaodih S. (2009). Landasan psikologi proses pendidikan. Bandung: Rosadakarya

National Council for Social Studies (NCSS). 15 Juli 2006. About NCSS. Diakses pada tanggal 10 Desember 2009, dari sciences (http://www/social studies.org/about/2006:1)

Savage, Tom V. (1996). Effective teaching in elementary social studies (Third edition).New Jersey: Englewood Cliffs.

Slavin, Robert E. (2005). Cooperative learning. London: Allyn \& Bacon

Sri Rumini. (2006). Psikologi pendidikan. Yogyakarta: Unit percetakan UNY.

Suharsimi Arikunto. (2002). Dasar-dasar evaluasi pendidikan. Jakarta: Bumi Aksara

Sutrisnoo Hadi. (2004). Statistik. Yogyakarta: Andi Offset

Suwarsih Madya. (1994). Panduan penelitian tindakan. Yogyakarta: Lemlit IKIP.

Permendiknas No 22 tahun 2006 tentang Standar Isi. 